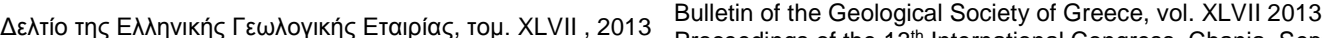



\title{
CSD CORRECTION AS A TOOL FOR ESTIMATING 3D
} BLOCK SIZE DISTRIBUTION

\author{
Rusi M. ${ }^{1}$ and Hoxha P. ${ }^{2}$ \\ ${ }^{1}$ Jacobs Consulting Geologists, baugeologie.at, Leobendorf, Austria, megirusi@yahoo.com. \\ ${ }^{2}$ Polytechnic University of Tirana, Albania, Faculty of Geology and Mining, Department of \\ Applied Geology, Environment and Geoinformatics, p_hoxha@yahoo.com.
}

\begin{abstract}
For the headrace Moglicë-Grabovë, part of Devoll Hydropower Project in Albania, two different techniques of tunnelling are planned: DS TBM for the Flysch series starting in Moglicë and Drill \& Blast for the Ophiolite section, starting in Grabovë. A major question concerning the tunnelling seems to find the point where DS-TBM excavation from the Moglicë side should stop to "wait" for the Drill\&Blast excavation from the Shemsit access tunnel side. Assumed that the so called "block in matrix" rock mass is very unfavourable, respectively disqualifying for TBM excavation. These mixtures of hard blocks embedded in weaker and finer matrix that are very difficult to characterize, frequently challenge the engineering geologists with the characterization, design and construction problems associated with them. Evaluating Block Size Distribution in the BiM rock zone of this project area has been only the first step in characterizing all the geological and geotechnical parameters of the rock mass which will influence a decision that has major economic consequences. CSDCorrections 1.39 is the program used to convert the two dimensional data gathered from thin sections, outcrops, photographs etc. to true three dimensional crystal size distributions (CSD).
\end{abstract}

Key words: Block\& Matrix, tunnelling, geotechnical parameters.

\section{Пврі́ $\eta \psi \eta$}

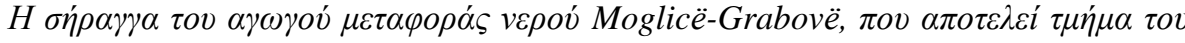

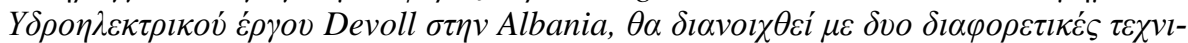

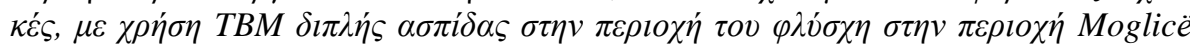

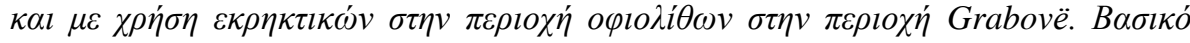

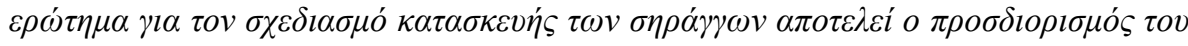



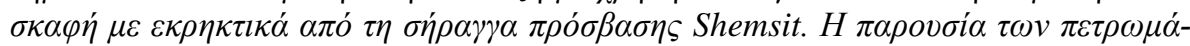

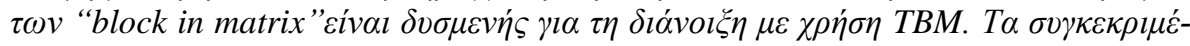

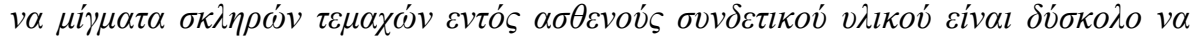

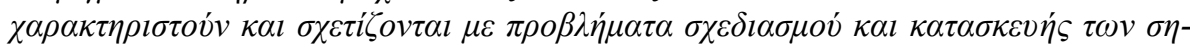

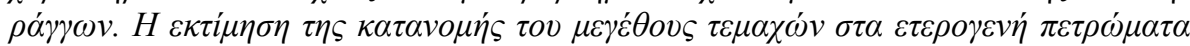

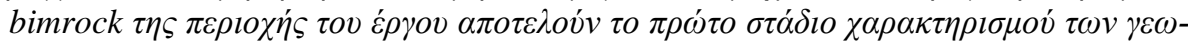

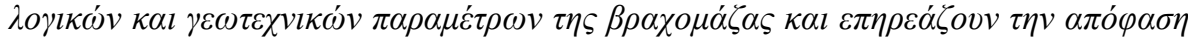

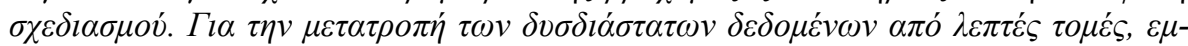

$\underline{\text { XLVII, No } 3-1854}$ 


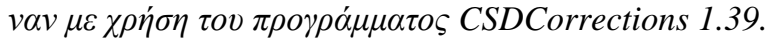

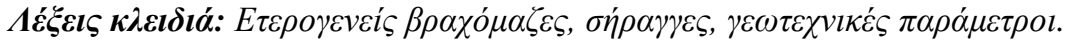

\section{Introduction}

Block-in-matrix rocks (BiM rocks) are mixtures of hard blocks embedded in weaker and finer matrix that are very difficult to characterize. Engineering geologists and the geotechnical engineers are frequently challenged by the characterization, design and construction problems associated with these heterogeneous geological mixtures. The Moglicë - Grabovë headrace tunnel in the Devoll Hydropower Project will go throw this type of Rock. Evaluating Block Size Distribution in the BiM rock zone of this project area is only the first step in characterizing all the geological and geotechnical parameters of the rock mass which will influence a decision that has major economic consequences.

1D Borings and 2D outcrop and maps of melanges and BiM rocks produce distributions that differ considerably from the 3D block size distributions, but there is promise that rules may yet be devised to estimate reliable block size distributions of melanges from chord length and surface distributions. Estimation of 3D particle size distributions from measurements in 1D and 2D are considered by stereology, a discipline blended from geometrical statistics, mathematics, microscopy, image analysis and empirical research. The paper at hand is an attempt to show why there is currently little reliable procedures for evaluating spatial distribution of block size, which are these methods and how can they be applied in the engineering practice.

\section{Material and Method}

\subsection{Description of the Project}

Devoll Hydropower Project consists of developing, planning, constructing and operating three hydropower plants along the Devoll River with an installed capacity of approx. $280 \mathrm{MW}$. DHP has the right to harness the hydrological potential of the Devoll River between 95 and $810 \mathrm{~m}$ above sea level, between Banjë Village in Elbasan District and Maliq Municipality in Korçë District. Through the three hydropower plants, Banjë HPP, Kokël HPP and Moglicë HPP the project will yearly generate approx. $800 \mathrm{GWh}$ of renewable, environmental-friendly energy, increasing the current electricity production in Albania by approx. 20\%. Based on average electricity consumption for Albanian household of $200 \mathrm{kWh} / \mathrm{month}$, the energy generated by the Devoll Hydropower Project can supply more than 300.000 Albanian households. Devoll Hydropower Project is one of the largest hydropower investments in the Balkans and the first large scale PublicPrivate-Partnership investment in Albania. The Moglicë Hydroelectric Project will utilise a head of $300 \mathrm{~m}$ along an about $22 \mathrm{~km}$ long stretch of Devoll River between $650 \mathrm{~m}$ a.s.l. and $350 \mathrm{~m}$ a.s.1.. The intake is situated upstream the $140 \mathrm{~m}$ high rock fill dam planned at Moglicë. The powerhouse is located in an underground cavern on the east bank of Devoll River and has two Francis units with total capacity of $165 \mathrm{MW}$. Transmission voltage is $220 \mathrm{kV}$ and estimated average annual energy production is $452 \mathrm{GWh}$. The tailrace outlet is at the upper end of the reservoir created by a $50 \mathrm{~m}$ high dam planned at Kokël. Approximately $11.7 \mathrm{~km}$ of tunnels with a diameter of $5.4 \mathrm{~m}$ will be excavated in different rock masses and 700m of which will go throw BiM rocks and mélanges.

\subsubsection{Geological and Tectonic Features}

Moglicë hydropower project is part of two major tectonic zones. The eastern most part lies within the Mirdita zone which consists of alloctone Jurasic Ophiolithic massifs of Vallamara, Voskopoja and Devoll. The last one is placed isolated in the west and it is separated from the other ophiolithic massifs throw a corridor which belongs to the Krasta tectonic zone. The Grabove-Moglice tunnel system will be excavated throw the Devoll ophiolithic massif of Mirdita zone as well as throw the

$\underline{\text { XLVII, No } 3-1855}$ 
flysch series of sandstones, clays, siltstones, conglomerates and limestone rocks of ages CreteEocene which belong to the Krasta zone. The lithological unit that will be studied in this paper represents the transitional area between the flysch series and ophiolitic body which consists of reprocessed material originating from the ophioliths as well as the flysch. The part of the Mélange which covers the ophiolithic complex is also part of Mirdita tectonic zone. We can distinguish four rock types within the area of the Mirdita heterogeneous melange. According to the principle used in this paper regarding their mechanical behaviour during excavation, all these rocks nevertheless the type, strength, the cementation degree etc. belong to the Block in Matrix rock type. But according to a genetic and lithological characterization, the encountered rock types in this area are more than one. After the competition of the detailed mapping campaign in 2011 it was concluded that the rock types are lhercolites / serpentinites, ophiolitic tectonic breccias, vulcanites, radiolarites and limestones. One of the results of this geological mapping phase was the preparation of the detailed longitudinal profiles and cross sections over the tunnel axis. The main rock lithologies that are found along the tunnel axes in the melange zone include sheared serpentinites, ophiolithic breccias, flysch formations of folded limestone, radiolarites, vulcanites.

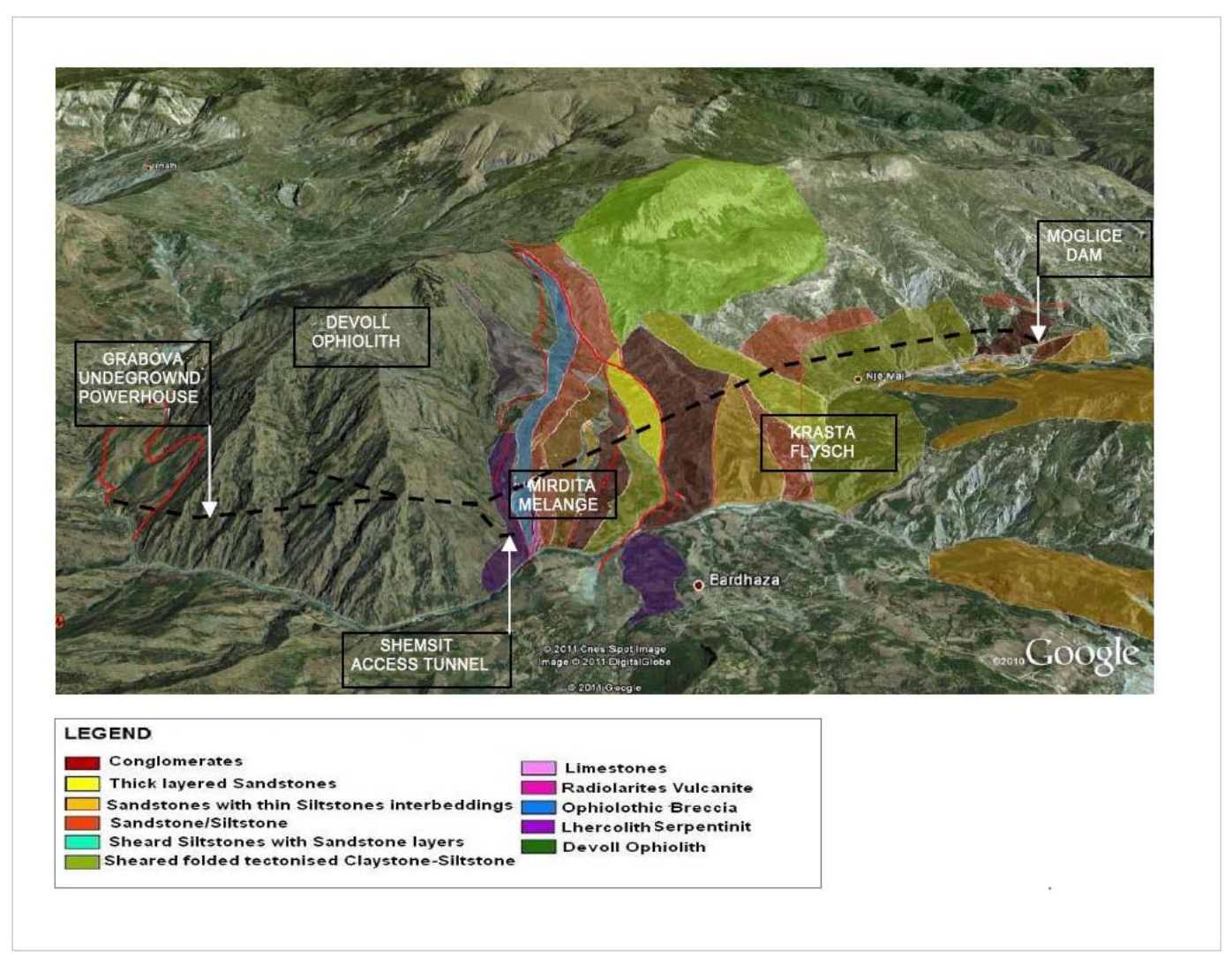

Figure 1 - The main lithologies mapped in the Mirdita melange zone.

\subsubsection{Tunnel Sections}

The alignment of the headrace tunnel was divided in sections referring to the present lithology and rock conditions. In total 28 tunnel-sections were defined along the overall length of 11.775 meters. Five of these sections which consist of approximately $700 \mathrm{~m}$ of tunnel alignment run throw the mélange zone. 


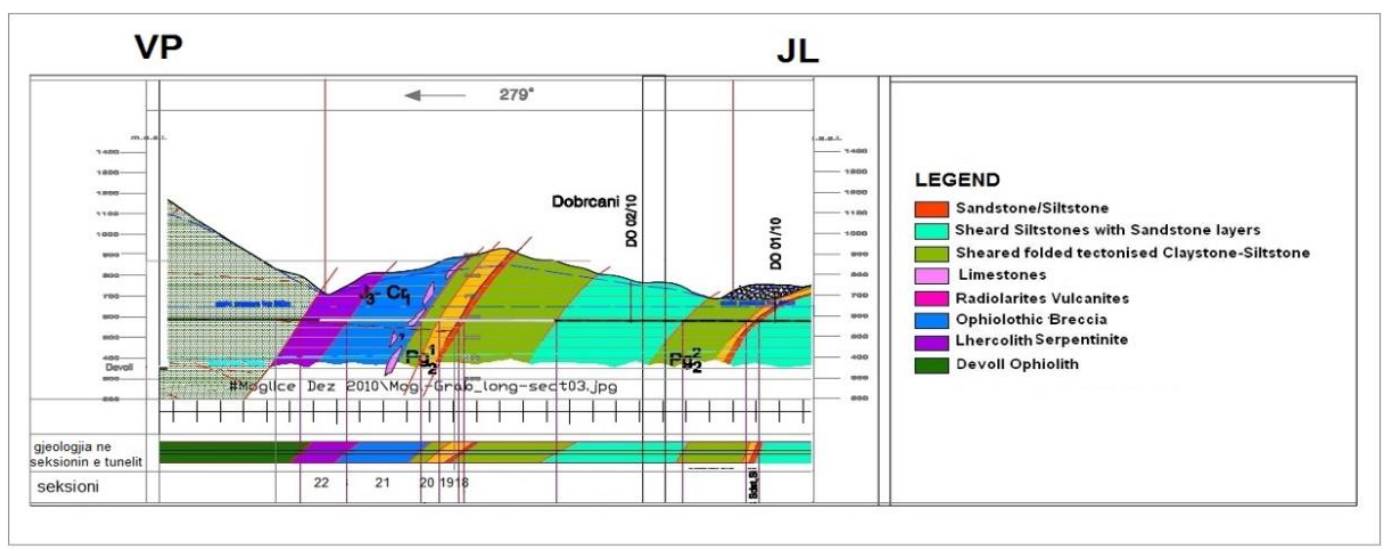

Figure 2 - Geological longitudinal section along tunnel axis in the Melange zone.

- From station $7450 \mathrm{~m}$ to approx. station $7550 \mathrm{~m}$ the tunnel alignment crosses section 18 and 19 and is expected to run through medium to thick bedded inter beddings of sandstone and siltstone layers with intercalations of silty shale layers over a length of approx. $100 \mathrm{~m}$. The strata dip moderately steep between 45 and $65^{\circ}$ to the NW to NNW. The borders of this section are not known very well.

- From station $7.550 \mathrm{~m}$ to approx. station $7.630 \mathrm{~m}$, section 20 , the tunnel alignment is expected to run through thin to medium bedded inter beddings of clayey shale and siltstone layers with intercalations of sandstone layers and randomly occurring lenticular lenses of conglomerates over a length of approx. $80 \mathrm{~m}$. The strata dips moderately steep between 45 and $65^{\circ}$ to $\mathrm{NW}$ to NNW.

- In section 21 from station $7.630 \mathrm{~m}$ to approx. station $7.950 \mathrm{~m}$ the tunnel alignment is expected to run through the rim related ophiolitic fault conglobreccia of the Devoll ophiolith over a length of approx. $320 \mathrm{~m}$. This rock can be named a real tectonic mélange. The strata dips 35 and $50^{\circ} \mathrm{NNW}$.

- From station $7.950 \mathrm{~m}$ until station $8.150 \mathrm{~m}$ the tunnel alignment passes section 22 and it is expected to run through intensely tectonized and highly alterated lherzolites that are already part of the Devoll ophiolith massif along a distance of approx. $200 \mathrm{~m}$.

\subsection{The Method}

The transition zone affected by the ophiolithic thrusting is the project area to which a special attention has been given during all the stages. Ophiolithic breccias and different melange zones, BIM rocks, together with intensively folded flysch formations and complex tectonic history were the object of the detailed mapping for this study. More than 100 outcrops have been documented in this area which is $700 \mathrm{~m}$ along the tunnel axes. The outcrops have been randomly selected throw scanlines. These outcrops have been photographed with high resolution cameras, and the pictures have been reworked afterwards.

\subsubsection{Guide to Digitalisation}

Before using the photograph for CSD it needs to be properly digitalised with image treatment programs and graphic programs (Adobe Photoshop, Adobe Illustrator, ImageJ etc.). Every block has to be outlined and layered separately. After outlining all the blocks, and turning off the picture layer it is needed to export the black and white image as an uncompressed tif. file to the ImageJ .This program makes possible the scale, measurement, particle analyses. 


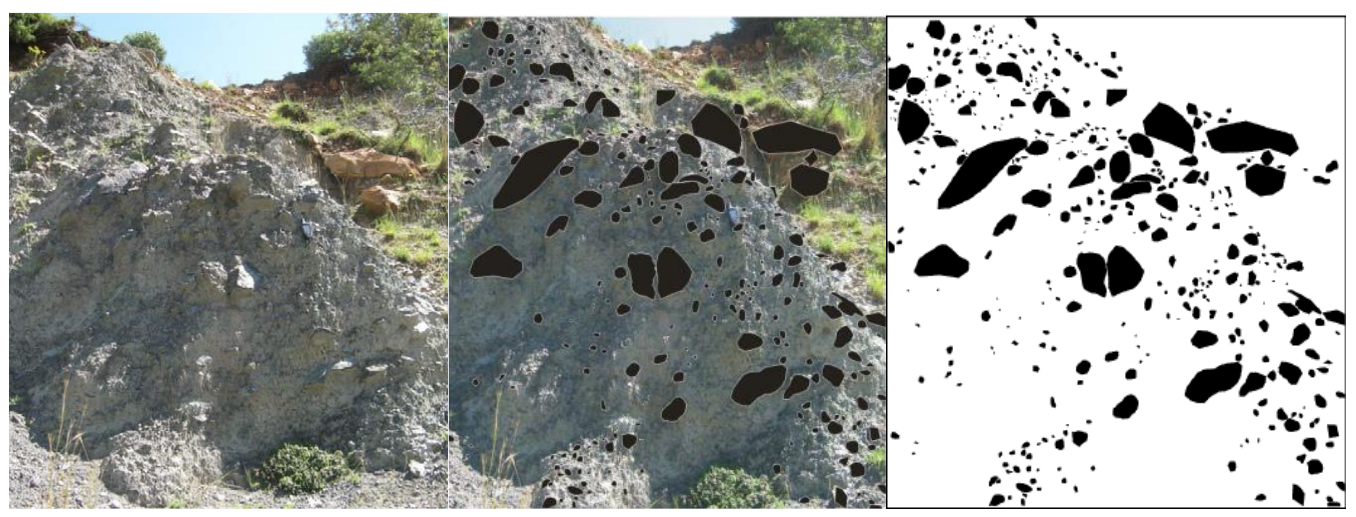

Figure 3- BiM rock outcrop and Digitalising Method.

\subsubsection{CSD Correction Utilisation}

CSD Corrections 1.39 is a program for converting two dimensional intersection data gathered from thin sections, outcrops, photographs etc. to true three dimensional crystal size distributions (CSD).The program constructs a solid of the dimensions indicated by the Short, Intermediate and Long dimensions. The orientation of the solid is constrained by the nature of the fabric (massive or foliated or lineated), the quality of the foliation (weak to strong) and the orientation of the desired section (parallel or normal to the fabric). This is sectioned by a plane placed a random distance from the centre of the solid. The outline of the intersection of the solid with the plane is determined and the length and width calculated. The distribution of these lengths and widths is used to correct the two dimensional for the cut section effect. The most likely intersection length (or width) is used to correct for tailing to smaller intersections. There is no tailing correction for intersections larger than the most likely intersection. This is rarely a problem if wide bins are used for the frequency distribution. After these tailing corrections have been made then corrections for the intersection probability effect are applied.

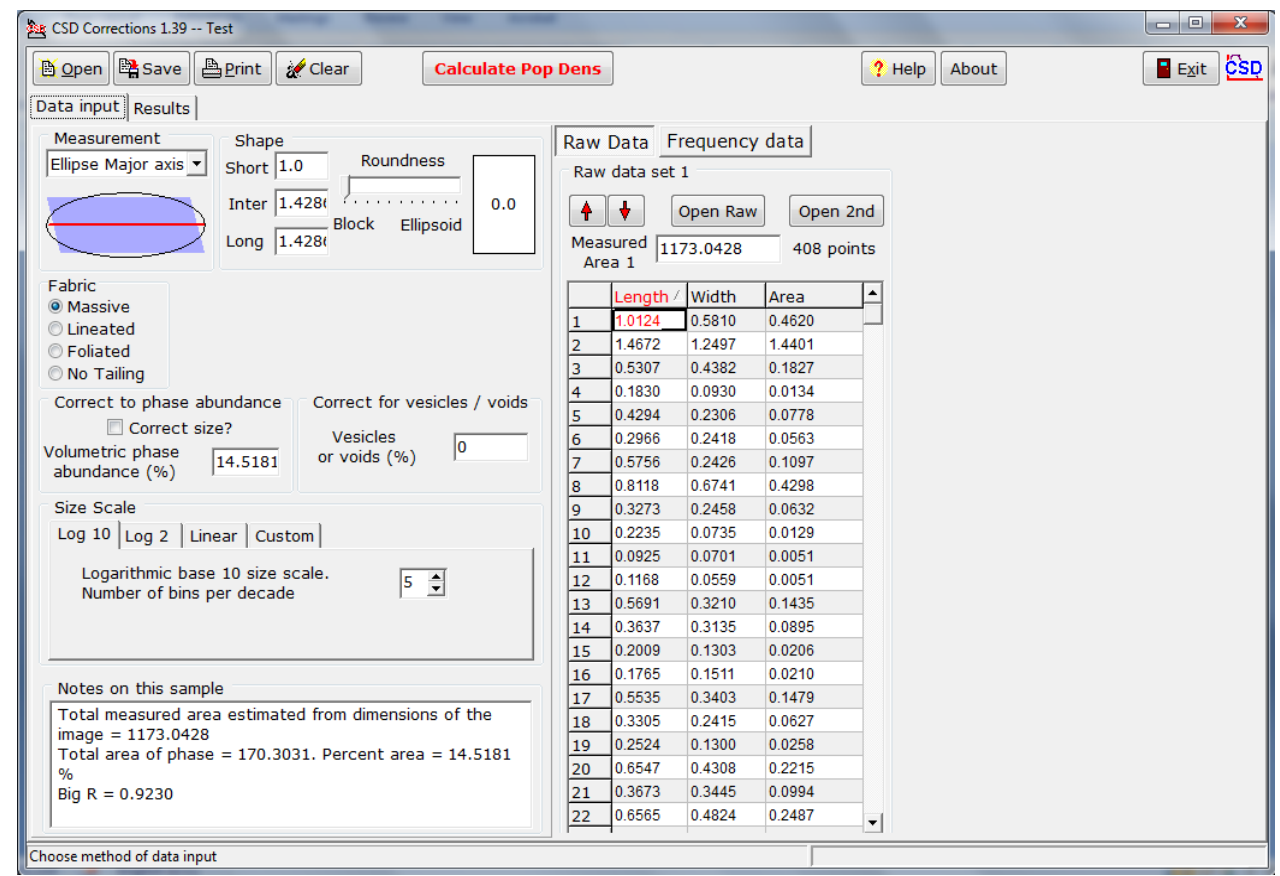

Figure 4 - CSD Correction Program Preview.

$\underline{\text { XLVII, No } 3-1858}$ 


\subsubsection{Data Entry}

Data can be entered as a list of Lengths, Widths and/or Areas. They can be typed directly into the grid or loaded from a simple file of data, with one measurement on each line. They can also be pasted from the clipboard if the cell has a dotted line around it (push the up and down arrows to get this). A maximum of ten thousand points can be measured. Rows can be deleted (with Del) or inserted (with Ins) if the cell has a dotted line around it. Data can be transferred directly from the ImageJ image processing program. It is possible to load two separate data sets. These will be summed. This may arise if data is measured at two different scales on the same rock. Data can also be loaded as a series of bins (size intervals) and number of measurements in each bin. The upper limit of the bin is put in the left column, with the number opposite in the right column. The last line must be the lower limit of smallest bin size and the number zero in the adjacent column. Bin sizes must decrease downwards. Rows, and hence bins, can be deleted (with Del) or inserted (with Ins) if the cell has a dotted line around it.

\section{Results and Discussion}

Results are shown in tables and diagrams. The table columns show the following data. Column 1: Corrected Size of the middle of the interval. The size is long dimension of parallelepipeds, the major axis of ellipsoids, or the diameter of spheres. Errors are calculated using only the counting statistics. No error has been accorded to the tailing corrections, because it is not clear how to do this. Hence the error bars should be regarded as minimum values. Column 2: The natural logarithm of the population density. Column 3, 4: The error limits of the population density. They are calculated from the square root of the number of intersections in each bin. This is propagated to the other bins. The error calculations do not take into account any error in the correction factors, and hence should be viewed as minimum errors. Column 5: Numbers of crystals per unit volume in the interval. This can be used to make other kinds of CSD diagram. Column 6: Per cent volume of crystals in each interval. The error in the larger size intervals can be significant.

The diagrams in show the crystal size distributions through the a) CSD in semi logarithmic diagram, b) Cumulative Distribution Function diagram, c) Fractal Dimension diagram and d) Population Density diagram.

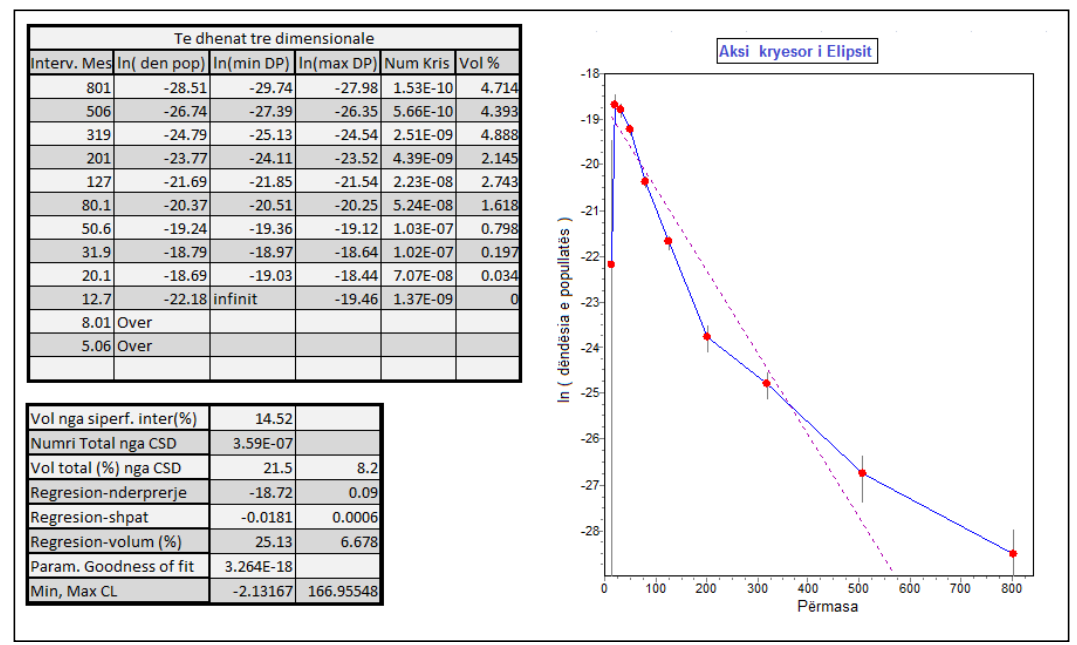

$\underline{\text { XLVII, No } 3-1859}$ 




Figure 5 - CSD in semi logarithmic diagram and Cumulative Distribution Function diagram.
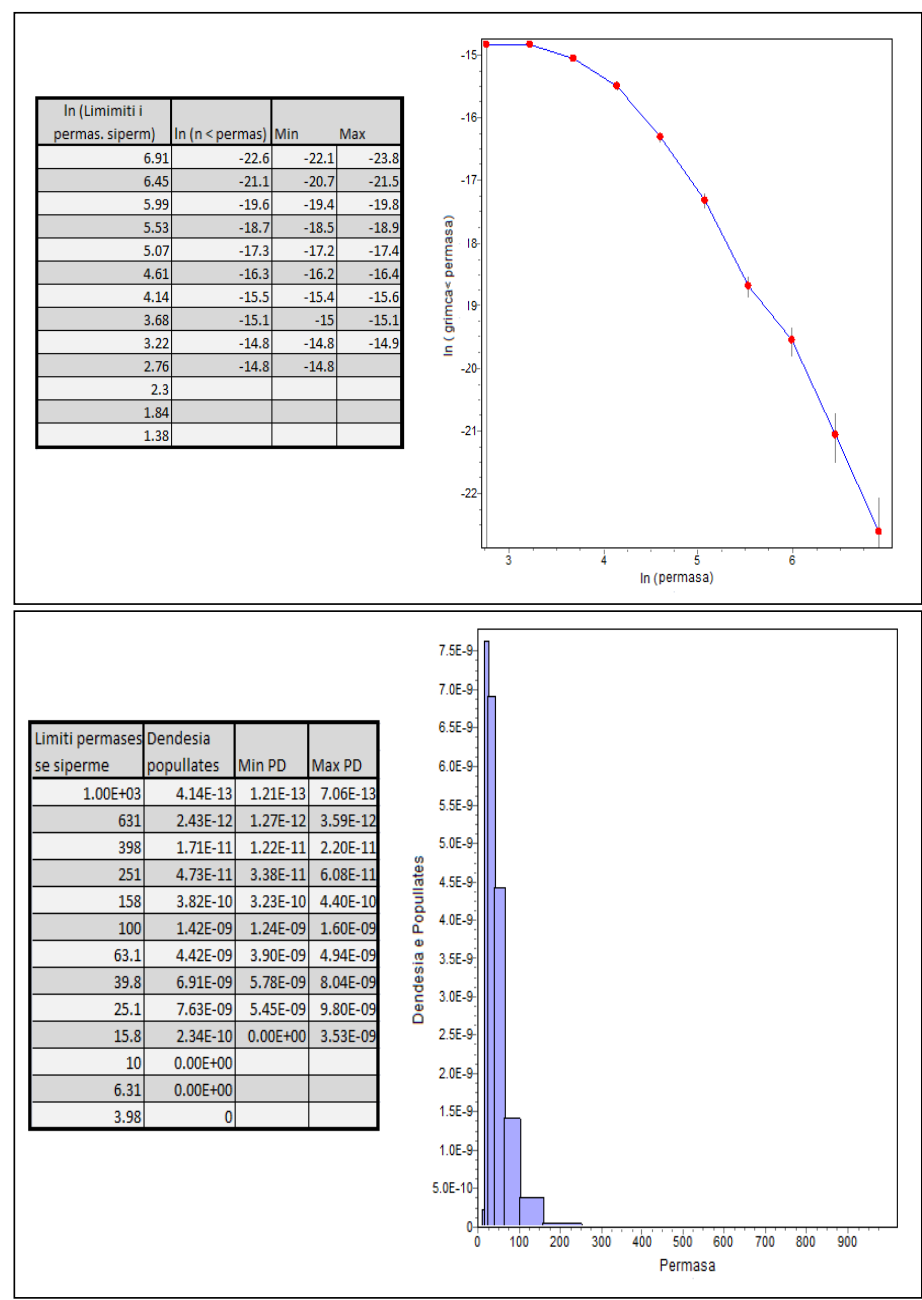

Figure 6- Fractal Dimension diagram and Population Density diagram.

$\underline{\text { XLVII. No } 3-1860}$ 


\subsection{Result Interpretation}

The semi-log graph or semi-log plot shows the visualizing data that are changing with an exponential relationship. If CSD is linear in this diagram it matches with the regression line and slope angle can be defined. It is obvious that the size distribution in this case at some point does not align very well with the law and the log shape makes the match impossible. Possible errors correspond to the statistical counting. The refraction of CSD-curve comes from mixed population (blocks of various proportions), but the proportions of the blocks are reasonable. It is noted that the overall low is that by increasing the size of the blocks their density decreases. But there is also a decrease in population density for blocks of smaller size, which is actually normal for natural samples. Such a reversal in small sizes in natural rocks may come as a result of many reasons, one of which may be inadequate spatial resolution. Log-normal distribution is a continuous probability distribution of a random variable whose logarithm is normally distributed. Cumulative data are transferred by using the normal standard cumulative distribution function inverse. In this diagram the log normal distribution appears as a straight line. Mixtures of log normal distributions are identified as two or more straight segments of the graphic. In our case, we can see four such distributions. In the third plot, the steepness of the line can be used to determine the Fractal dimension distribution. In the cases where the line has more than one visible slope, the distribution can be described as multi Fractal. In our chart although the curve does not match $100 \%$ the straight line, it can be determined only one Fractal dimension with a value of approximately 1.45.The histogram is a graphical representation showing a visual impression of the distribution of data. It is an estimate of the probability distribution of a continuous variable. It proves the first statement that the overall low is that by increasing the size of the blocks their density decreases.

\subsection{Discussion}

Mélanges and BiM rocks are very common in nature and a lot of engineering projects are obligated to be constructed in these chaotic rocks. Excavating tunnels in BiM rocks can result highly problematic for a number of different reasons, one of which is the fact that in these types of rocks the blocks vary in size. Knowledge of the size distribution of blocks is a key parameter that should be evaluated in these studies. Between the maximum and minimum block size, in the scale range, it is important that the blocks are characterized by their respective volumes. The methods presentet in this paper intend to help geologists and engineers in the characterization of melange blocks. CSD Correction is a useful tool in the field of mineralogy and petrology, but there are still doubts about its use in big 'sample' size. With a more detailed research and study it can be helpful for the engineering geologist and for further developing the BiM rock study. The CSD produced by the program for small size sections have reasonable errors from $10 \%$, but for complex shapes the application of CSD Correction seems to make just a first aproxximation, so care should be taken for the interpretations.

\section{Acknowledgments}

We are very grateful to $\mathrm{PhD}$ Sven Jacobs, who encouraged with the persuasion of this topic and spent extra time helping to achieve better results.

This paper would not have been possible without the support of DHP who gave us the permit to access their reports. Besides, we would like to thank the Faculty of Geology and Mining in Tirana for providing us with a good environment and facilities to complete this work. 


\section{References}

Adam D., Markiewicz R., Brunner M. 2011. Block -in-Matrix structure- tunnelling in hard soil and/or weak rock, Proceedings of the 15th European Conference on soil Mechanics and Geotechnical Engineering, A. Anagnostopoulou et al. IOS Press, pp 607-1614.

American Geological Institute 1987. Glossary of Geology, Bates R.L. and Jackson J.A. (eds.), 3rd Edition; American Geological Institute, Alexandria.

Brugger C.R. and Hammer J.E. 2010. Crystal size distribution analysis of plagioclase in experimentally decompressed hydrous rhyodacite magma, Earth and Planetary Science Letters, pp 246-254.

Button E., Riedmuller G., Schuber W., Klima K. and Medley E. 2003. Tunneling in tectonic mélanges- accommodating the impacts of Geomechanical complexities and anisotropic rock mass fabrics, Bulleting of engineering geology and Environment, pp 1-24.

Fasching F. and Vanek R. 2011. Engineering geological characterization of fault rocks and fault zones, Geomecanics and tunneling, Volume 4, No 3, pp 181-194.

Ferreira T., Rasband W., Image J. 2012. User Guide, ImageJ/Fiju1.46.

Haneberg C.W. 2004. Simulation of 3D Block Populations to characterize Outcrop Sampling Bias in BiM rocks, FELSBAU 22 No 5, pp 9- 26.

Higgins M. D. 2002. Closure in crystal size distributions (CSD), verifications of CSD calculations, and the significance of CSD fans, American Mineralogist, January, v. 87, pp 171-175

Higgins M. D. 2006. Quantitative textural measurements in igneous and metamorphic petrology. Cambridge University Press - August, 265p.

Jacobs S., Jacobs S., Rusi M. and Bartl N. Devoll 2011._20110408_Moglice-Headrace-GeolLongsection-A0_10000. Geological Report. HPP Moglica.

Jacobs S., Rusi M., Bartl N. and Jacobs S. 2011. Harnessing of Hydropower Potential of Devoll River, Geological Report, Part III-HPP Moglica, Chapter 7, Waterway Moglicë-Grabovë. 7.4 Headrace tunnel Dobercan-Shemsit: Mirdita Melange.

Jagnow R., Dorsey J. and Rushmeier H. 2004. Stereological Techniques for solid textures, p 7.

Laznicka P. 1998. Breccias and Coarse Fragmentites: Petrology, Environments, Associations, Ores 25 of Developments in Economic Geology: Elseveir, New York, 1988, p 823.

Lindquist E.S. 1994. The strength and deformation properties of Melange, PhD Dissertation, 1994.

Lindquist E. S. and Goodman R.E. 1994. The Strength and Deformation Properties of a Physical Model Melange, Proceedings of First North American Rock Mechanics Symposium, Austin, Texas (June 13,1994): Rotterdam, Netherlands, AT. Balkema.

Marinos P. and Hoek E. 2001. Estimating the geotechnical properties of the heterogeneous rock masses such as flysch, Bulletin of Engineering Geology and environment, 60, p 85-92.

Marsh B.D. 1988. Crystal size distribution (CSD) in rocks and the kinetics and dynamics of crystallization I. Theory. Contributions to Mineralogy and Petrology, Springer-Verlag 99, pp 277-291.

Meco S., Aliaj S. and Turku I. 2000. Geology of Albania, contribution to the regional geology of the Earth, Volume 28, Borntraeger brothers, Berlin, Stuttgart, 205 p.

Medley E.W. and Zekkos D. 2011. Geopractitioner approaches to working with antisocial mélanges, The Geological Socirty of America, Special paper 480, pp 261- 277.

Medley E.W. 2002. Estimating Block Size Distributions of Melanges and Similar Block- inMatrix Rocks (Bimrocks), Proceedings of $5^{\text {th }}$ North American Rock Mechanics Symposium (NARMS),Toronto, Canada, pp 509-606.

Medley E.W. 2002. Some guidelines to characterization of Franchescan mélanges and other BiM rocks. Appendix B to Melange and fault rocks exposed in and around abandoned quarry at the Schmidt lane recycling center, El Cerrito, California.

Medley E.W. 1994. The engineering characterization of Melanges and similar Block in Matrix Rocks, PhD Dissertation 1994. 
Mock A. and Jerram D.A. 2005. Cristal Size Distributions in three dimentions. Insights from the 3D reconstruction of a highly porphyritic rhyolite, Journal of Petrology, Volume 46, Number 8 .

Perfect E. 1997. Fractal models for the fragmentation of rocks and soils: a review, pp 1525-1541

Raymond L.A. 1984. Classification of Melanges, in Melanges: Their nature, origin and significance; 228 of special paper, Boulder, Colorado, Geological society of America, pp 7-10.

Robertson A. and Shallo M. 2000. Mesozoic-Tertiary tectonic evolution of Albania in its regional Eastern Meditettanean context, Tectonophysics 316, pp 197-254.

Russ, J.C. and Dehoff R.T. 2000. Practical Stereology. Plenum Press, Second Edition. New York, $381 \mathrm{p}$.

Sahagian D.L. and Proussevitch A.A. 1998. 3D particle size distributions from 2D observations: stereology for natural applications, J. Volcanology and Geothermal Research, pp 173-196

Shallo M. 1990. Ophiolithic melange and flyschoidal sediments of the Tithonian-Lower Cretaceous in Albania, Terra Nova, Wiley-Blackwell, Oxford, 2, pp 470-488.

Tremblay A., Meshi A., Bedard J. H. 2009. Oceanic core complex and ancient oceanic lithosphere: In sights from Iapetan and Tethyan ophiolithes (Canada and Albania.2009), Tectonophysics, (473), pp 36-52.

Turcotte D. L. 1992. Fractals and Chaos in Geology and Geophysics. Cambridge, 221 p.

Wakabayashi J. and Dilek Y. 2011. Characteristics and tectonic settings of mélanges, and their significance for societal and engineering problems, Geological Society of America, Special papers, 480, pp v-x

Wakabayashi J. and Medley E. 2004. Geological characterization of Mélanges for practitioners FELSBAU 22 (2004) Nr5, pp 10-18.

http://depcom.uqac.ca/ mhiggins/

http://depcom.uqac.ca/ mhiggins//csdcorrections.html

http://bimrocks.com/

http://www.rocscience.com/education/hoeks_corner 